
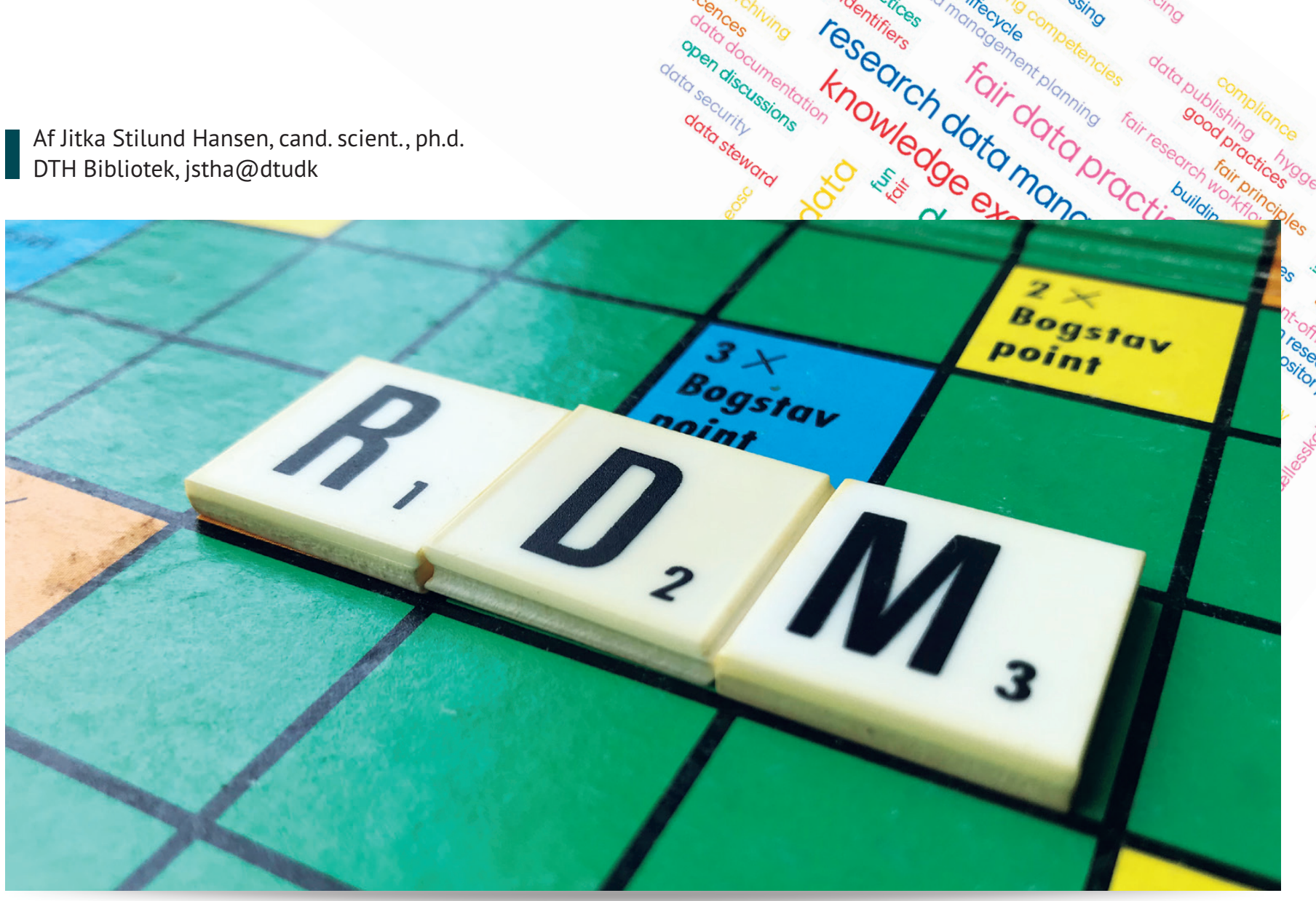

RDM eller Research Data Management (RDM) handler om at håndtere forskningsdata bedst muligt. Foto: Stefan Katic

\title{
RDM - et netværk for fair og åben adgang til forskningsdata
}

\author{
Nationalt Research Data Management Netværk er et \\ nyt initiativ fra danske RDM-support-medarbejdere. \\ Vær med!
}

Det var alt sammen ret forvirrende. DMP, DEFF, DM Forum, DeiC, FAIR, RDM, RDA.

I juni 2019 blev jeg ansat i research data management-teamet på biblioteket ved Danmarks Tekniske Universitet og en ny verden skulle åbne sig for mig. Research data management (RDM) handler om, hvordan vi på bedste vis håndterer forskningsdata og jeg skulle hjælpe med at understøtte og videreudvikle de services, som DTU Bibliotek tilbyder sine forskere.

Meget hurtigt blev jeg derfor introduceret til den lange række begreber og akronymer.

I 2019 var adskillige projekter og fora i gang på RDM-området og jeg blev indlemmet i forskellige aktiviteter.
Således lærte jeg i løbet af nogle måneder relativt ubesværet at navigere i forkortelserne. Min mulighed for at indgå i nogle af projekterne under DEFF og DM Forum var afgørende for at jeg fik en indsigt i og praktisk erfaring med, hvad RDM indebærer. Ligeledes gav formidlingsaktiviteterne under DM Forum nyttig information om specielt det danske RDM-landskab. Den danske node under Research Data Alliance (RDA) introducerede mig til internationale fora, hvor strategiske indsatser søsættes og koordineres.

Det viste sig, at akronymerne hviler på aldeles åbne og dygtige mennesker, som gerne vil dele deres viden, de kan lide at diskutere og selvom de har travlt, så kan de levere produkter af høj kvalitet (Boks 1). Det var meget givende at møde så engagerede og vidende kolleger så snarligt efter mit spring ud i RDM-dybet.

\section{Netværket spindes}

Håndtering af forskningsdata på struktureret og bæredygtig vis kræver viden, interesse og kompetencer, og mine kolleger på danske vidensinstitutioner har udviklet værktøjer (Boks 1) til netop at fremme viden og kompetencer inden for RDM. Disse produkter benytter vi os i høj grad af i både strategisk og praktisk arbejde på de enkelte institutioner.

Som skitseret er aktiviteterne tidligere sket i regi af for eksempel DM Forum under DeiC, DEFF og den danske RDA-node. Da disse initiativer udløb i 2020 opstod et behov for at vedligeholde kontakt og mulighed for sparring. Nationalt RDM Netværk blev derfor etableret i november 2020 med 
det primære formål at fungere som et uafhængigt sparrings-netværk for personer med arbejdsområde inden for eller interesse for RDM.

Mange af medlemmerne sidder i en front-office-funktion på institutionerne. Målet er derfor, at Nationalt RDM Netværk kan samarbejde og sparre på front office-delen, for eksempel omkring udbredelse af FAIR og undervisningstiltag. Netværket kan benyttes til at udvikle og samarbejde omkring kompetencer og værktøjer og er åben for al vidensudveksling og nye initiativer på RDM-området. Vi mødes ofte til arrangementer i ind-og udland, så netværket har også et meget internationalt fokus. Ikke mindst via medlemmernes deltagelse i internationale projekter og organisationer, såsom OpenAIRE, RDA og NeiC.

\section{Fremtiden er FAIR...}

En national strategi for data management ifølge FAIR-principperne lanceres $\mathrm{i}$ år. Mange af netværkets medlemmer har påvirket strategien i form af høringssvar, som deres institutioners forskere har bidraget til. Dette er blot ét eksempel på, hvordan netværkets medlemmer aktivt holder øje med data-politikker og rejser relevante problematikker. Behovet for et stærkt netværk til at understøtte udviklingen af kompetencer inden for FAIR-data tydeliggøres i den nationale strategi.
Den omfatter alt fra praksis-ændringer, måling af FAIR-modenhed og adgang til infrastruktur og vidensressourcer, som støtter udbredelsen af FAIR data.

\section{... og åben}

Et andet område, der også vil kræve front-office-funktionernes bevågenhed, er Open Science-forventningerne under Horizon Europe-rammeprogrammet. EU har et skærpet fokus på Open Science, hvilket tydeliggøres i krav om FAIR data og åben adgang til artikler og i videst muligt omfang også til data.

\section{Ansøgningerne til Horizon Europe forventes at blive vurderet på deres RDM-strategier, ligesom data mana- gement planer bliver obligatoriske "deliverables". Forskningsbiblioteker- nes evne til at vejlede om open access til artikler vil blive testet nu, ligesom tilpassede kurser i FAIR-data og DMP-skrivning sandsynligvis vil blive efterspurgt. Om EU's retning og den nationale FAIR-strategi får indflydelse på danske bevillingsgiveres krav, bliver også et spændende område at følge de næste år.}

Mange RDM-ansatte er frontløbere inden for Open Science og FAIR, så store mængder af ressourcer ligger allerede frit tilgængelige på forskellige platforme. Måske bliver et af netværkets opgaver at hjælpe hinanden med at identificere de bedste værktøjer og tilpasse dem til nationale forhold?

\section{Det første netværksmøde}

Medlemmerne i Nationalt RDM Netværket vil på skift arrangere møder med fagligt indhold og det første afholdes 15. juni af Det Kongelige Bibliotek (se boks 2). Programmet byder på oplæg og diskussion om data-repositorier. Der bliver oplæg om det europæiske Open Science-økosystem (EOSC), og hvordan EOSC er struktureret.

Desuden vil vores erfaringer med egne repositorier baseret på Dataverse, Clarin og Figshare blive delt. Den service vi tilbyder forskerne, er konstant under udvikling og vi håber, at det afspejles i vores netværksmøder.

Både medlemskab af netværket og deltagelse i dette møde er gratis. Vores aktiviteter dækkes af vores institutioner, og er til gavn for den front office-rolle og service, som medlemmerne tilbyder egne forskere. Du behøver ikke sidde i en front-office-funktion for at få gavn af et medlemskab. Du skal blot interessere dig for den dynamiske verden, som skabes af FAIR forskningselementer, Open Science og god håndtering af forskningsdata..

\section{Her har medlemmerne været involveret}

E-learn modulet howtofair.dk

National koordinering af Data Stewardshipuddannelse i Danmark

Forskningsdata.dk/fairytale

FAIR data og RDM i citizen science-projekter - en arbejdspakke under DEFF-projektet "Identificering af fag-og forskningsbibliotekernes rolle i forhold til udbredelse og understøttelse af Citizen Science"

\section{Nationalt RDM-netværk}

Alle med interesse for RDM og FAIR-principperne kan blive medlem. Medlemskab er gratis, da institutionerne på skift står for administration, møder og arrangementer.

Find mere info om netværket, medlemskab og vores arrangementer på forskningsdata.dk/rdmnetvaerk/

| 2021 står DTU for administrationen, så kontakt datamanagement@dtu.dk, hvis du vil høre mere eller ønsker at blive medlem.

Jitka Stilund Hansen er akademisk medarbejder ved DTU Bibliotek. Jitka er medlem af LIBER's Citizen Science-gruppe, men bruger det meste af sin tid på at udvikle og drive services til DTU's forskere.

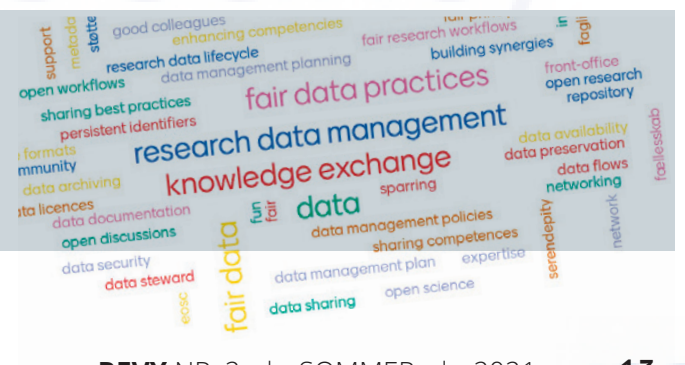

